\title{
LOOP-MEDIATED ISOTHERMAL AMPLIFICATION (LAMP) DALAM PENEGAKAN DIAGNOSIS INFEKSI PARASIT MALARIA BERBASIS MOLEKULER
}

\author{
Jhons Fatriyadi Suwandi ${ }^{1}$ \\ ${ }^{1}$ Bagian Mikrobiologi dan Parasitologi Fakultas Kedokteran Universitas Lampung, Program Parasitologi Klinik \\ Fakultas Kedokteran Universitas Indonesia, \\ e-mail: yadisuwandi04@gmail.com
}

\begin{abstract}
Diagnosis of malaria is an important part of the malaria elimination program. Fast process, accurate and inexpensive is a hope in the diagnosis of malaria, especially in remote areas, in emergency situations or when microscopic staffs are not available. The RDT and RDTs tests that have been used to diagnose malaria, sometimes have less than expected accuracy. Microscopy is the gold standard in routine examination, often constrained when microscopic staff are not present. The experience of microscopic staff will also affect the results of the examination. Nested PCR is often used to confirm microscopy results, but requires special equipment and laboratories so it is expensive. To answer the shortcomings of the previous examination method, the loop-mediated isothermal ampli fi cation (LAMP) was developed as a method of diagnosis. LAMP as a molecular-based assay method has high accuracy, with sensitivity and specificity in almost all previous studies showing more than 90\%. LAMP can also detect plasmodium species from malaria patients in endemic or non-endemic areas (imported cases), in pregnancy, in conditions of low parasitemia density and in areas with low transmission.
\end{abstract}

Keywords: LAMP, Malaria, Diagnosis, Microscopy, nested PCR

\section{ABSTRAK}

Penegakan diagnosis malaria merupakan hal penting dalam program eleminasi malaria. Proses yang cepat, akurat dan murah merupakan harapan dalam diagnosis malaria, khususnya pada daerah remote area, pada kondisi gawat darurat atau pada saat ketidaktersediaan tenaga mikroskopis. Pemeriksaan RDT dan RDTs yang telah digunakan untuk menegakkan diagnosis malaria, terkadang memiliki akurasi yang kurang diharapkan. Pemeriksaan mikroskopis sebagai gold standard, sering terkendala saat tidak ada tenaga mikroskopis. Pengalaman tenaga mikroskopis juga akan mempengaruhi hasil pemeriksaan. Nested PCR sering digunakan untuk mengkonfirmasi hasil pemeriksaan mikroskopis, namun membutuhkan peralatan dan laboratorium khusus sehingga membutuhkan biaya yang mahal. Untuk menjawab kekurangan pada metode pemeriksaan sebelumnya, maka loop-mediated isothermal amplification (LAMP) dikembangkan sebagai metode diagnosis. LAMP sebagai metode pemeriksaan yang berbasis molekuler memiliki akurasi yang tinggi, dengan sensitifitas dan spesifisitas pada hampir semua penelitian sebelumnya lebih dari $90 \%$. LAMP juga dapat mendeteksi spesies plasmodium dari pasien malaria pada daerah endemis atau non-endemis (kasus impor), pada kehamilan, pada kondisi densitas parasitemia yang rendah dan pada daerah dengan low transmission.

Kata kunci: LAMP, Malaria, Diagnosis, Mikroskopis, nested PCR 


\section{PENDAHULUAN}

Malaria merupakan penyakit infeksi parasit protozoa yang endemik pada berbagai belahan dunia termasuk di Indonesia. Kejadian malaria di dunia pada tahun 2019 dilaporkan sebanyak 229 juta kasus dengan kematian sebesar 409.000 kematian. Tingginya angka kejadian malaria di dunia, terbanyak dilaporkan dari benua Afrika ${ }^{1}$. Di Indonesia sendiri kejadian malaria masih tinggi walaupun tergolong low transmission. Nilai API Indonesia secara nasioal pada tahun 2019 adalah sebesar 0,93 per 1000 penduduk, dengan API tertinggi ditemukan di Papua $(64,03)$, Papua Barat $(7,38)$ dan Nusa Tenggara Timur $(2,37)$, sedangkan Nilai API pada propinsi lainnya masih dibawah 1. Namun demikian tetap dilaporkan 3 Propinsi yang memiliki API 0 yaitu Kalimantan Barat, DI Yogyakarta dan Banten².

Penyakit infeksi yang disebabkan oleh 5 spesies protozoa dari genus plasmodium ini memiliki spektrum gejala klinis yang luas, mulai dari asimptomatik sampai ditemukan adanya komplikasi yang berat. Hal ini sering menyulitkan dalam menegakkan diagnosis malaria sehingga akan berpengaruh pada pemberian terapi yang pada akhirnya akan mempengaruhi keberhasilan pengobatan. Beberapa pemeriksaan telah dikaji untuk dapat membantu menegakkan diagnosis seperti pemeriksaan mikroskopis, RDT, dan pemeriksaan molekuler dengan PCR atau QPCR. Pemeriksaan mikroskopis dengan menemukan parasit malaria pada pemeriksaan darah tebal dan atau darah tipis merupakan Gold standar dalam penegakan diagnosis malaria saat ini ${ }^{3,4,5,6,7}$.

Pemeriksaan Gold standar mikroskopis saat ini masih menjadi ujung tombak pemeriksaan yang digunakan. Pemeriksaan mikroskopis sangat bergantung pada ketersedian tenaga mikroskopis yang handal dalam menemukan parasit plasmodium dalam sedian. Sering kali saat tidak adanya tenaga mikroskopis yang handal, maka akan terjadi penurunan kualitas hasil pemeriksaan yang pada akhitnya akan terjadi underdiagnosis atau misdiagnosis. Kemampuan mendeteksi dari tenaga mikroskopis sangat bervariasi tergantung pengalaman dan jam terbangnya. Batas deteksi ini bervariasi antara 5-100 parasit/ $\mu \mathrm{L}^{4,5,7}$

Pemeriksaan RDT yang ditemukan sangat membantu mempercepat penegakan diagnosis malaria terutama pada remote area atau pada ruang gawat darurat. Pemeriksaan RDT yang ada sebagian besar memiliki sensitifitas dan spesifisitas yang baik terutama pada malaria falciparum, tetapi tidak untuk spesies yang lain seperti malaria vivax, malaria knowlesi dan lainnya. Selain itu dilaporkan juga bahwa batas kemampuan mendeteksi parasit dari RDT cukup tinggi yaitu $100-200$ parasit/ $\mu \mathrm{L}$. Kondisi ini menginisiasi pengembangan RDT menjadi RDT ultrasensitif untuk mendeteksi infeksi karier amsimptomatik, penderita pada daerah non endemik, parasitemia yang rendah dan remote area ${ }^{3,7,8}$.

Adanya keterbatasan-keterbatasan dalam metode pemeriksaan sebelumnya, maka pengembangan metode diagnosis dengan deteksi molekuler menjadi satu pilihan dalam menegakkan diagnosis. Hal ini tentunya untuk meningkatkan sensitifitas dan spesifisitas pemeriksaan. Pemeriksaan molekuler parasit malaria menggunakan PCR atau Q-PCR telah terbukti dapat mendeteksi parasitemia rendah $\leq 0,05$ parasit $/ \mu \mathrm{L}$. Berbagai macam metode PCR telah dikembangkan untuk pemeriksaan malaria sehingga dapat dipelajari genetik dari 
plasmodium tersebut dan dapat dibedakan antar spesiesnya bahkan sampai ke level strain. Namun terdapat suatu kelemahan dari pemeriksaan molekuler berbasis PCR adalah diperlukan tempat yang khusus, perlu pelatihan tenaga yang melakukan pemeriksaan dan perlu peralatan lengkap. Kondisi ini tentunya tidak mendukung untuk dilakukan pada laboratorium pada fasilitas layanan kesehatan tingkat pertama atau Rumah Sakit type D atau C sekalipun. Keadaan ini menyebabkan pemeriksaan dengan menggunakan PCR menjadi mahal dan lama ${ }^{4,7}$.

Loop-mediated isothermal amplifikasi (LAMP) DNA pertama kali dikenalkan pada tahun $2000^{\circ}$. Penggunaan LAMP pertama kali untuk pemeriksaan malaria dilakukan pada tahun 2006 oleh Poon, et al. ${ }^{10}$. Pemeriksaan ini memiliki pripsip pemeriksaan dengan pendektan metode molekuler isotermal menggunakan DNA polimerase dari Bacillus stearothermophilus, yang memiliki aktivitas perpindahan untai yang mengarah ke siklus otomatis DNA tanpa perubahan suhu dengan target maateri genetik pada mitokondria Plasmodium. Metode amplifikasi DNA ini lebih mudah dan lebih murah dibandingkan dengan PCR, karena peralatan dan fasilitas laboratorium yang dibutuhkan lebih sedikit. Dengan berbasis molekuler pemeriksaan ini tentunya akan memiliki sensitivitas yang lebih tinggi daripada pemeriksaan mikroskop dan RDTs. ${ }^{6,7,8,11}$

Berdasarkan latar belakang yang telah disampaikan mengenai kemampuan pemeriksaan mikroskopis, RDT, RDTs dan LAMP, maka tulisan ini bertujuan untuk membahas tentang amplifikasi materi genetik, prinsip kerja pemeriksaan LAMP, pemeriksaan LAMP untuk mendeteksi Plasmodium sp dan sensitifitas - spesifisitas LAMP untuk pemeriksaan malaria pada daerah endemik, nonendemik atau pada kasus khusus seperti malaria pada kehamilan.

\section{PEMBAHASAN}

\section{Amplifikasi Materi Genetik}

Amplifikasi asam nukleat sebagai materi genetik merupakan hal penting dalam bidang kedokteran dan kesehatan khususnya dalam menegakkan diagnosis suatu penyakit infeksi, kelainan dan kondisi genetik. Selama ini amplifikasi materi genetik masih berbasis PCR dengan beberapa metode amplifikasi yang telah ditemukan, seperti nucleic acid sequencebased amplification (NASBA), self-sustained sequence replication (3SR) dan strand displacement amplification (SDA). Pada amplifikasi berbasis PCR klasik masih menggunakan langkah denaturasi DNA untuk setiap siklus sintesis DNA nya. Modifikasi pada metode 3SR dan NASBA menghilangkan denaturasi panas dengan menggunakan serangkaian reaksi transkripsi dan rekasi reverse transcriptions untuk mengamplifikasi sequent target. Hal yang sama ditemukan juga pada metode SDA yang menghilangkan langkah denaturasi panas dalam siklus sintesis DNA dengan menggunakan satu set enzim restriksi dan sintesis untai DNA untai dengan modifikasi nukleotida sebagai substrat ${ }^{9}$.

Metode ini dapat mengamplifikasi asam nukleat target dengan sesuai dengan ukurannya, dengan detection limit kurang dari 10 copies dalam satu jam atau lebih walaupun masih memiliki kekurangan yang perlu untuk diatasi. Metode ini masih membutuhkan ketepatan instrumen untuk mengamplifikasi atau metode yang rumit untuk mendeteksi 
produk amplifikasi karena spesifisitas yang tidak baik pada pemilihan target sekuen. Hal ini menyebabkan metode ini belum dapat dipakai secara luas untuk diagnostik rutin. Metode NASBA dan 3SR tidak menggunakan siklus termal dan menggunakan suhu yang relatif rendah untuk amplifikasi, yaitu $40^{\circ} \mathrm{C}$. Metode SDA mencoba mengatasi kekurangan ini dengan menggunakan empat primer dan kondisi isotermal untuk amplifikasi, tetapi masih memiliki titik lemah: peningkatan digestion DNA yang tidak relevan yang terkandung dalam sampel serta penggunaan nukleotida termodifikasi sebagai substrat yang mahal. Meskipun penggunaan beberapa primer, seperti pada nested PCR dan SDA telah meningkatkan spesifisitas amplifikasi untuk target sekuen, namun residu ko-amplifikasi dari sekuen yang tidak relevan masih menyebabkan kurangnya hasil amplifikasi asam nukleat, terutama untuk penggunaan diagnostik $^{9}$.

\section{Prinsip Kerja LAMP}

Metode LAMP ini menggunakan prinsip auto-cycling strand displacement DNA yang dilakukan oleh DNA polimerase dengan high strand displacement activity dan satu set primer yang terdiri dari dua inner primer dan dua outer primer. Keempat primer tersebut pada awal reaksi digunakan semua, namun selama siklus hanya inner primer yang digunakan untuk sintesis DNA. Inner primer terdiri dari forward inner primer (FIP) dan backward inner primer (BIP), dan masing-masing berisi dua sekuen berbeda yang sesuai dengan sekuen sense dan antisense dari DNA target. Sampel DNA yang berisi urutan target dan empat primer didenaturasi oleh panas dan dengan cepat didinginkan di atas es. Pada reaksi LAMP enzim DNA polimerase yang digunakan adalah Bst DNA polimerase. Dengan penambahan enzim ini pada suhu $65^{\circ} \mathrm{C}$ maka reaksi LAMP akan dimulai. Proses ini akan berlangsung selama 1 jam $^{9,12}$.

Produk akhir dari reaksi LAMP adalah campuran stem-loop DNA dengan berbagai panjang stem dan struktur seperti kembang kol dengan beberapa loop yang dibentuk selama anealing antara pengulangan sekuen target secara bergantian dalam untai yang sama. Penggunaan empat primer pada langkah awal dari reaksi LAMP dan dua primer pada langkah berikutnya memastikan spesifisitas yang tinggi untuk amplifikasi target. Selain itu, pada reaksi LAMP empat primer secara bersamaan digunakan untuk memulai sintesis DNA dari DNA original yang tidak diamplifikasi untuk menghasilkan stem-loop DNA untuk siklus LAMP berikutnya, di mana target dikenali oleh empat sekuen primer tersebut. Oleh karena itu, selektivitas target diharapkan lebih tinggi dibandingkan dengan reaksi pada PCR dan SDA $^{9}$.

\section{Pemeriksaan LAMP untuk Deteksi Plasmodium sp.}

Masih tingginya angka kejadian malaria dan perlunya penegakan diagnosis dang tepat dan cepat agar pengobatan dapat segera dilakukan, maka perlu dilakukan pengembangan metode diagnosis. Metode penegakan diagnosis berbasis molekuler menjadi suatu pilihan yang perlu dikembangkan, salah satunya adalah metode LAMP. Metode ini telah dilakuka untuk mengamplifikasi berbagai DNA termasuk dalam bidang diagnosis penyakit menular. 
Pada penegakan diagnosis malaria selama ini, pemeriksaan mikroskopis masih menajdi gold standar, walaupun pemeriksaan mikroskopis hanya dapat mendeteksi 4 spesies Plasmodium dari 5 spesies yang menyebabkan malaria pada manusia. Identifikasi $P$. knowlesi masih mengandarlkan pemeriksaan molekuler.

Pada tahun 2006, telah dikembangkan tes molekuler sederhana dan murah untuk mendeteksi gen RNA ribosom $18 \mathrm{~S}$ yang sangat conserve pada $P$. falciparum dengan menggunakan teknologi loop-mediated isothermal amplification (LAMP). Pemeriksaan ini tidak menimbulkan reaksi silang dengan DNA dari $P$. vivax, $P$. malariae, atau $P$. ovale, atau dengan DNA manusia. Pada penelitian ini telah dipelajari spesimen darah dari pasien malaria falciparum $(n=102)$ yang dirawat pada Rumah Sakit di Bangkok, Thailand. Sebagai kontrol digunakan 100 sampel darah dari donor sukarelawan yang sehat dalam populasi yang sama. Penyiapan sampel darah hanya dilakukan dengan pemanasan sampai suhu $99^{\circ} \mathrm{C}$ selama 10 menit tanpa melakukan isolasi DNA. Sebanyak $50 \mu \mathrm{L}$ darah yang dipanaskan diambil $2 \mu \mathrm{L}$ supernatannya untuk dilakukan pemeriksaan dengan metode LAMP. Hasil penelitian yang didapat menunjukkan bahwa dari 102 sampel darah yang positif pada pemeriksaan mikroskopis, 96 diantaranya positif dalam pemeriksaan LAMP. Untuk keperluan validasi temuan tersebut, penelitinya melakukan pemurnian DNA dari semua sampel darah dan melakukan pemeriksaan PCR untuk $P$. falciparum. Hasil pemeriksaan PCR menunjukkan 3 dari 6 spesimen yang negatif pada pemeriksaan LAMP, juga negatif pada pemeriksaan PCR. Ketiga sampel tersebut kemudian ditemukan positif $P$. malariae pada pemeriksaan PCR. Hal ini menunjukkan bahwa ketiga sampel ini salah diagnosis dengan pemeriksaan mikroskopis. Pada kelompok kontrol terdapat 99 dari 100 sampel negatif dalam pemeriksaan LAMP. Satu sampel yang positif pada pemeriksaan LAMP juga ditemukan positif pada pemeriksaan PCR $P$. falciparum. Hal ini mungkin terjadi karena sampel diambil dari individu dengan infeksi $P$. falciparum asimtomatik yang banyak ditemukan pada daerah endemik. Hasil penelitian ini menunjukkan bahawa sensitivitas dan spesifisitas uji LAMP masing-masing adalah 95\% dan 99\%. Pada penelitian tersebut juga didapatkan dugaan bahwa DNA polimerase Bacillus stearothermophilus (Bst) yang digunakan dalam reaksi LAMP lebih resisten terhadap panas dibandingkan dengan DNA polimerasi pada PCR. Salah satu hal menarik dari uji LAMP adalah kemampuannya untuk menghasilkan endapan putih magnesium pirofosfat dalam jumlah besar pada reaksi yang positif. Hal ini memungkinkan identifikasi reaksi positif dengan mudah melalui inspeksi visual. Untuk mengevaluasi kelayakan dan konsistensi penafsiran reaksi LAMP dengan visual dilakukan pengamatan oleh seorang yang tidak terlatih dan tidak memiliki pengetahuan sebelumnya tentang hasil reaksi LAMP. Pada pengamatan tersebut diklasifikasikan sebagai positif, negatif, atau ambigu berdasarkan kekeruhan reaksi. Dari 202 sampel yang diperiksa, hasilnya konsisten dengan hasil sebelumnya, dan hanya 4 sampel yang diklasifikasikan sebagai ambigu ${ }^{10}$.

Pada penelitian yang dilakukan oleh Poon, et al pada tahun 2006 tersebut juga dilaporkan perbandingannya dengan pemeriksaan mikroskopis. Seperti diektahui bahwa batas ambang mikroskopis oleh ahli mikroskopis berpengalaman adalah sekitar 50 
parasit / uL. Untuk membandingkan pemeriksaan LAMP dengan mikroskopis, dilakukan pengenceran serial 10 spesimen klinis dengan jumlah parasit mulai dari 72 hingga 46,890 parasit / UL dan mengujinya dengan uji LAMP. Hasilnya menunjukkan bahwa jumlah parasit minimal dalam darah untuk reaksi positif pemeriksaan LAMP adalah sekitar 6 parasit/ $\mu \mathrm{L}$. Disamping itu dilaporkan juga bahwa pemeriksaan LAMP dapat digunakan sebagai metode objektif untuk menentukan jumlah parasit dalam sampel darah. Untuk menguji reaktivitas pemeriksaan LAMP dengan strain yang ditemukan di wilayah lain, peneliti tersebut menguji sampel darah dari 21 pasien dengan infeksi $P$. falciparum atau $P$. vivax dari tempat lain. Hasil yang didapat pemeriksaan LAMP dan PCR memberikan hasil yang identik yaitu 10 sampel positif $P$. falciparum. Salah satu dari 10 sampel yang pada awalnya didiagnosis $P$. vivax dengan metode mikroskopis, menunjukkan hasil negatif pada pemeriksaan PCR untuk $P$. vivax sehingga tidak ada koinfeksi $P$. falciparum dan $P$. vivax pada pasien terrsebut. Hasil ini yang memperkuat spesifisitas pemeriksaan LAMP ${ }^{10}$.

Setelah penelitian pada tahun 2006 tersebut, banyak penelitian-penelitian lain yang melaporkan pemeriksaan LAMP untuk mendeteksi plasmodium. Beberapa tahun terakhir penelitian pengujian LAMP sudah sangat berkembang dan dilakukan pada beberapa kondisi. Peneltiian-penelitian tersebut ingin menguji kemungkinan penetapan LAMP sebagai metode pemeriksaan yang mendampingi pemeriksaan mikroskopis dan RDT yang sudah lebih dahulu digunakan untuk pemeriksaan rutin.
Pada tahun 2019, Mhamilawa, et al mempublikasikan hasil penelitiannya pada sampel dengan low density parasitemia. Penelitian tersebut membandingkan deteksi Plasmodium falciparum dengan menggunakan pemeriksaan mikroskopis, LAMP dan PCR setelah pengobatan dengan ArtemetherLumefantrine hari ketiga di Tanzania menunjukkan hasil angka positif sebesar $0 \%$ untuk pemeriksaan mikroskopis dan $84,8 \%$ untuk pemeriksaan PCR dan LAMP. Sensitivitas dan spesifisitas LAMP terhadap PCR adalah $100 \%(95 \% \mathrm{Cl}, 96,1-100)$ dan $77,4 \%(95 \% \mathrm{Cl}, 58,9-90,4)$ ketika kepadatan parasit yang ditentukan PCR secara kuantitatif adalah $\geq$ dua parasit $/ \mu \mathrm{L}$. Pemeriksaan LAMP memiliki akurasi diagnostik yang sebanding dengan PCR dan berpotensi untuk digunakan sebagai alat menentukan angka positif pada hari ke-3, walaupun masih membutuhkan penelitian lebih lanjut ${ }^{11}$.

Pada tahun 2019, Kudyba et al juga melaporkan penelitian dengan pemeriksaan LAMP pada penderita malaria di Brazil dengan metode malachite green loop-mediated isothermal amplification (MG-LAMP). Pemeriksaan MG-LAMP merupakan pemeriksaan LAMP berbasis warna (colorimetric). Sasaran subjek penelitian adalah penderita malaria dengan low density parasitemia atau asimptomatik pada saat surveilance malaria. Hasil dari penelitian tersebut menunjukkan dari 91 subjek penelitian, sensitivitas dan spesifisitas keseluruhan MG-LAMP masing-masing adalah 90,0\% (95\% confidence interval (Cl) 76,3497,21\%) dan 94\% (95\% Cl 83,76-98,77\%). Sensitivitas dan spesifisitas mikroskopis lokal masing-masing adalah $83 \%(95 \% \mathrm{Cl} 67,22-$ $92,66 \%$ ) dan $100 \%$ (95\% Cl 93,02-100,00\%). 
Real Time PCR mendeteksi enam infeksi campuran (infeksi Plasmodium falciparum dan Plasmodium vivax); dua di antaranya juga terdeteksi oleh MG-LAMP dan satu dengan mikroskop. Mikroskopis tidak mendeteksi adanya infeksi Plasmodium pada 26 peserta sehat; MG-LAMP mendeteksi Plasmodium pada lima kasus serta pemeriksaan real time PCR mendeteksi tiga kasus ${ }^{13}$.

Penelitian lainnya dilaporkan pada tahun 2018, yang mengkaji pemeriksaan LAMP untuk skrining malaria pada wanita hamil di Kolombia menggunakan darah perifer dan darah plasenta. Hasil dari penelitian tersebut menunjukkan bahwa pada spesimen yang menggunakan darah perifer, LAMP menunjukkan peningkatan sensitivitas $(100,0 \%)$ bila dibandingkan dengan pemeriksaan mikroskopos $79,5 \%$ dan RDT $76,9 \%$ ( $p<0,01)$. Pada wanita afebris, yang sensitivitas LAMP dapat mencapai dua kali lebih tinggi dari pemerksaan mikroskopis dan RDT. Secara keseluruhan tampak bahwa terdapat kesamaan yang tinggi antara pemeriksaan LAMP dan nested PCR. Untuk spesifisitas menunjukkan angka yang sama untuk semua jenis pemeriksaan yaitu $100 \%$. Pada spesimen darah plasenta, pemeriksaan LAMP menunjukkan peningkatan sensitivitas empat kali lipat $(88,9 \%)$ bila dibandingkan dengan pemeriksaan mikroskopis dan RDT $(22,2 \%)^{14}$.

Penelitian yang mengkaji pemeriksaan LAMP untuk pasien malaria impor pada daerah non endemik dipublikasika pada tahun 2017 oleh Ponce, et al. Hasil penelitian tersebut melaporkan pemeriksaan pada 310 sampel darah yang terkait kasus malaria impor. Pemeriksaan mikroskopis digunakan untuk standar diagnosis. Real time PCR digunakan sebagai standar dan LAMP digunakan sebagai tes indeks dalam studi ini. Nilai sensitivitas, spesifisitas, nilai prediksi positif dan nilai prediksi negatif untuk pemeriksaan LAMP adalah 100\%, 98.13\%, 95.51\%, dan 100\% dibandingkan dengan PCR. Nilai prediksi negatif yang tinggi menunjukkan bahwa LAMP dapat digunakan untuk skrining kasus malaria impor di negara non-endemik, terutama pada saat tenaga mikroskopis tidak tersedia ${ }^{15}$.

Penelitian lain pada tahun 2017 yang mengamati performa pemeriksaan LAMP untuk menegakkan diagnosis malaria pada wanita hamil di Ethiopia. Pada penelitian tersebut nested $P C R$ sebagai gold standard untuk pemeriksaan. Hasil penelitian menunjukkan bahwa sensitivitas pemeriksaan mikroskopis dan RDT adalah masing-masing $90 \%$ dan $70 \%$, dan spesifisitas masing-masing adalah $98,7 \%$ dan 97,4\%. Untuk pemeriksaan LAMP sensitifitas adalah $100 \%$ dan spesifisitas $93,5 \%$ dibandingkan dengan nested $P C R^{6}$.

Penelitian lain pada tahun 2018 melaporkan perbandingan antara pemeriksaan RDT dan LAMP pada daerah low transmission di Nemibia Afika. Pada penelitian tersebut pemeriksaan LAMP justru sebagai gold standard. Hasil penelitian tersebut menunjukkan Prevalensi infeksi malaria falciparum tergolong rendah 0,8\% (16/1919) dengan menggunakan RDT dan 2,2\% (43/1919) pada pemeriksaan LAMP. Sensitivitas dan spesifisitas RDT masingmasing adalah $2,3 \%$ dan $99,2 \%$. Penelitian tersebut menyimpulkan bahwa adanya riwayat demam dan RDT standar tidak dapat digunakan untuk menegakkan diagnosis ${ }^{16}$. 
Penelitian lain yang melaporkan hasilnya pada tahun 2016 dalam mendeteksi $P$. vivax dengan menggunakan high throughput colorimetric LAMP (HtLAMP). Hasil dari penelitian tersebut menunjukkan bahwa perkiraan batas deteksi adalah 1,4 parasit / $\mu \mathrm{L}$ pada high throughput $L A M P$ - $P$. vivax (HtLAMP-Pv). Primer uji menunjukkan reaktivitas silang dengan $P$. knowlesi tetapi tidak dengan Plasmodium spp lainnya. Uji lapangan HtLAMP-Pv dilakukan dengan menggunakan 149 sampel dari penderita malaria bergejala (64 P. vivax, 17 P. falciparum, 56 P. knowlesi, 7 P. malariae, 1 campuran $P$. knowlesi / P. Vivax, dan 4 spesimen diekslusi). Jika dibandingkan dengan multipleks PCR, HtLAMP-Pv menunjukkan sensitivitas untuk $P$. vivax sebesar 95\% (95\% Cl 87- 99\%); 61/64), dan spesifisitas $100 \%$ (95\% Cl $86-100 \%)$; 25/25) ketika sampel $P$. knowlesi dikeluarkan. Pengujian HtLAMP-Pv pada 112 sampel asimptomatik dari masyarakat sebagai kontrol, menunjukkan sensitivitas $71 \%(95 \% \mathrm{Cl} 29$ 96\%; 5/7) dan spesifisitas 93\% (95\% Cl87$97 \% ; 98 / 105)^{8}$.

Pada tahun 2013 Polley, et al telah melaporkan pemeriksaan LAMP untuk menegakkan diagnosis pada kasus malaria impor dengan melakukan deteksi genus dan spesies $P$. falciparum. Hasil penelitian tersebut menunjukkan bahwa sebanyak 705 sampel yang dilakukan pemeriksaan memperoleh sensitivitas dan spesifisitas masing-masing adalah $98,4 \%$ dan $98,1 \%$ untuk primer LAMP P. falciparum dan $97,0 \%$ dan $99,2 \%$ untuk primer genus Plasmodium. Hal ini menunjukkan bahwa LAMP Malaria memiliki keakuratan diagnostik yang mirip dengan nested $P C R$, dengan waktu pengerjaan yang sangat singkat, dan lebih unggul dari pemeriksaan mikroskopis ${ }^{3}$.

Pada tahun 2014 dilaporkan pemeriksaan LAMP untuk menegakkan diagnosis pada infeksi malaria di daerah endemik di Thailand. Hasil penelitian tersebut melaporkan sebanyak 899 pasien demam dianalisa dalam penelitian. Pemeriksaan LAMP yang pertama dilakukan pada 219 pasien, dan hasilnya dibandingkan dengan dua jenis RDT histidine-rich protein (HRP)-2 dan pemeriksaan mikroskopis sebagai standar emas. Ekstraksi DNA untuk pemeriksaan LAMP dilakukan dengan metode perebusan sederhana, dan hasil tes dinilai secara visual. Nilai sensitivitas, spesifisitas, nilai prediksi positif (PPV), dan nilai prediksi negatif (NPV) masing-masing untuk LAMP adalah $95,7 \%, 100 \%$, 100\%, dan $98 \%$, dan untuk RDT masing-masing adalah $98,6 \%$, 98\%, 95,8\%, dan 99,3\%. Sensitivitas RDT tampak sedikit lebih tinggi dibandingkan LAMP, hal ini kemungkinan dikarenakan pada pemeriksaan RDT dikatakan positif bila terdapat salah satu yang positif dari dua pemeriksaan RDT. Pemeriksaan LAMP kedua selanjutnya dilakukan pada 680 pasien, dan hasilnya dibandingkan dengan mikroskop sebagai gold standard. Hasilnya menunjukkan Sensitivitas, spesifitas, PPV, NPV, dan akurasi diagnostik LAMP masing-masing adalah $88,9 \%$, 96,9\%, 92,2\%, 95,5\%, dan $94,6 \%$. Berdasarkan hasil penelitian ini tampak bahwa pemeriksaan LAMP di Thailand layak dilakukan di lokasi lapangan dengan sumber daya teknis yang terbatas. Selain itu, metode perebusan cepat untuk mengekstraksi DNA dari bercak darah kering terbukti sederhana, cepat, dan cocok untuk digunakan di lapangan ${ }^{5}$. 
Penelitian lain yang juga dilaporkan pada tahun 2014 dengan melakukan deteksi alpha-tubulin DNA $P$. vivax. Hasil penelitian menunjukkan bahwa pemeriksaan LAMP $\alpha$ tubulin sangat sensitif dengan batas deteksi aadalah 100 copies gen $P$. vivax $\alpha$-tubulin per reaksi dalam 50 menit. Pemeriksaan Ini memiliki target khusus hanya pada $P$. vivax. Hasil pemeriksaan menunjukkan bahwa sensitivitas yang tinggi ( $P<0,001$ versus mikroskop; $P=0,0023$ versus $R D T$ ) ketika nested PCR digunakan sebagai gold standard. Penelitian ini menunjukkan bahwa uji $P$. vivax a-tubulin LAMP dapat digunakan untuk mendiagnosis infeksi awal malaria vivax merupakan alat diagnostik molekuler alternatif dan point of care test adalah dapat membantu mencegah penularan pada daerah endemik ${ }^{4}$.

Penelitian pada tahun 2015 dengan melakukan perbandingan pemeriksaan noninstrumented nucleic acid amplification loopmediated isothermal amplification (NINALAMP) dengan pemeriksaan mikroskopis dan nested PCR sebagai gold standard untuk menegakkan diagnosis malaria di Ethiopia. Hasil penelitian menyebutkan sebanyak 82 sampel diuji dalam analisis primer dengan nilai sensitivitas dan spesifisitas adalah sebesar 96,8\% (interval kepercayaan 95\% (Cl), 83,2\% $99,5 \%$ ) dan $84,3 \%$ (95\% Cl, 71,4\% - 92,9\%), masing-masing untuk deteksi genus Plasmodium, dan $100 \%(95 \% \mathrm{Cl}, 75.1 \%$ $100 \%$ ) dan $81.2 \%$ (95\% Cl, 69.9\% - 89.6\%), masing-masing untuk deteksi parasit $P$. falciparum. Pemeriksaan mikroskopis menunjukkan sensitivitas dan spesifisitas masing-masing sebesar $93,6 \%(95 \% \mathrm{Cl}, 78,5 \%$ - 99,0\%) dan 98,0\% (95\% Cl, 89,5\% - 99,7\%) untuk mendeteksi parasit Plasmodium. Pemeriksaan NINA-LAMP sangat sensitif untuk diagnosis malaria dan deteksi infeksi parasit Plasmodium baik pada tingkat genus maupun spesies bila dibandingkan dengan nested $P C R$. Pemeriksaan NINA-LAMP lebih sensitif daripada mikroskop untuk mendeteksi $P$. falciparum dan diferensiasinya dari spesies non-falciparum ${ }^{17}$.

Hasil terbaru yang dilaporkan dari uji meta analasis yang membandingkan akurasi pemeriksaan LAMP, RDTs mikroskopis dan PCR pada tahun 2020 menunjukkan bahwa terdapat Enam puluh enam studi yang diterbitkan antara 2006 dan 2019, yang menganalisis 30.641 tes LAMP. Sensitivitas gabungan pemeriksaan LAMP berkisar antara 96\% sampai $98 \%$. Spesifitas yang dikumpulkan dari LAMP adalah sekitar 95\%. Penelitian meta-analisis ini menegaskan bahwa metode LAMP kuat untuk mendiagnosis malaria, baik pada orang yang bergejala maupun tanpa gejala. Oleh karena itu, pemeriksaan LAMP penting untuk pengendalian malaria ${ }^{7}$.

Berdasarkan hasil beberapa penelitian sejak 2006 sampai 2020, tampak bahwa pemeriksaan LAMP untuk mendeteksi $P$. falciparum maupun spesies plasmodium lainnya menunjukkan keakurasian yang tinggi. Nilai sensitifitas dan spesifisitas menunjukkan angka yang tinggi berkisar pada angka $90 \%$. Pemeriksaan yang sederhana; tidak memerlukan siklus termal, tidak menggunakan reagen yang mahal, waktu yang singkat menjadi suatu keuntungan tersendiri dari pemeriksaan ini. Pada pemeriksaan ini pun tidak diperlukan adanya proses isolasi yang rumit, proses pemanasan pada sampel darah sudah dapat mengisolasi DNA tersebut untuk kemudian dilakukan pemeriksaan LAMP. Hal ini tentunya tidak ditemukan pada pemeriksaan 
berbasis molekuler lainnya yang selama ini dilakukan dengan menggunakan PCR. Hasil meta analisis yang telah di publikasikan pada tahun 2020 (7) sangat mendukung bahwa pemeriksaan LAMP layak untuk dilakukan sebagai alternatif pemeriksaan dalam menegakkan diagnosis malaria berbasis molekuler.

\section{KESIMPULAN}

Pada pemeriksaan laboratorium untuk menegakkan diagnosis malaria berbasis molekuler, proses amplifikasi materi genetik sangat penting untuk memperbanyaknya sehingga dapat dianalisis. Amplifikasi materi genetik berbasis PCR dengan beberapa metode amplifikasi, seperti nucleic acid sequence-based amplification (NASBA), selfsustained sequence replication (3SR) dan strand displacement amplification (SDA). Pemeriksaan LAMP merupakan salah satu metode amplifikasi materi genetik yang tidak berbasis PCR. Pemeriksaan LAMP memiliki akurasi pemeriksaan yang tinggi, dengan nilai sensitifitas dan spesifisitas hampir semua penelitian yang dilakukan diatas 90\%. Pemeriksaan LAMP juga dapat mendeteksi spesies plasmodium dari penderita malaria pada daerah endemis, non-endemis (kasus impor), pada kehamilan, pada kondisi densitas parasitemia yang rendah dan pada daerah dengan low transmission.

\section{REFERENSI}

1. World Health Organization. World Malaria Report. Geneva; 2020. 238 p.

2. Kementerian Kesehatan Republik Indonesia. Profil Kesehatan Indonesia Tahun 2019. Jakarta; 2018.

3. Polley SD, González IJ, Mohamed D, Daly R, Bowers K, Watson J, et al. Clinical evaluation of a loopmediated amplification kit for diagnosis of imported malaria. J Infect Dis. 2013;208(4):637-44.

4. Dinzouna-Boutamba SD, Yang HW, Joo SY, Jeong S, Na BK, Inoue N, et al. The development of loopmediated isothermal amplification targeting alpha-tubulin DNA for the rapid detection of Plasmodium vivax. Malar J. 2014;13(1):1-9.

5. Sattabongkot J, Tsuboi T, Han ET, Bantuchai S, Buates S. Loop-mediated isothermal amplification assay for rapid diagnosis of malaria infections in an area of endemicity in Thailand. $J$ Clin Microbiol. 2014;52(5):1471-7.

6. Tegegne B, Getie S, Lemma W, Mohon AN, Pillai DR. Performance of loop-mediated isothermal amplification (LAMP) for the diagnosis of malaria among malaria suspected pregnant women in Northwest Ethiopia. Malar J. 2017;16(1):1-7.

7. Picot S, Cucherat M, Bienvenu AL. Systematic review and meta-analysis of diagnostic accuracy of loopmediated isothermal amplification (LAMP) methods compared with microscopy, polymerase chain reaction and rapid diagnostic tests for malaria diagnosis. Int J Infect Dis [Internet]. 2020;98:408-19. Available from: https://doi.org/10.1016/j.ijid.2020.07.009

8. Britton S, Cheng Q, Grigg MJ, Poole CB, Pasay C, William T, et al. Sensitive Detection of Plasmodium vivax Using a High-Throughput, Colourimetric Loop Mediated Isothermal Amplification (HtLAMP) Platform: A Potential Novel Tool for Malaria Elimination. PLoS Negl Trop Dis. 2016;10(2):1-16.

9. Notomi T, Okayama H, Masubuchi H, Yonekawa T, Watanabe K, Amino N, et al. Loop-mediated isothermal amplification of DNA. Nucleic Acids Res. 2000;28(12).

10. Poon LLM, Wong BWY, Ma EHT, Chan KH, Chow LMC, Abeyewickreme W, et al. Sensitive and 
Inexpensive Molecular Test for Falciparum Malaria: Detecting Plasmodium falciparum DNA Directly from Heat-Treated Blood by Loop-Mediated Isothermal Amplification. Clin Chem. 2006;52(2):303-6.

11. Mhamilawa LE, Aydin-Schmidt B, Mmbando BP, Ngasala B, Morris U. Detection of plasmodium falciparum by light microscopy, loop-mediated isothermal amplification, and polymerase chain reaction on day 3 after initiation of artemether-lumefantrine treatment for uncomplicated malaria in Bagamoyo District, Tanzania: A compar. Am J Trop Med Hyg. 2019;101(5):1144-7.

12. Feranisa A. Komparasi Antara Polymerase Chain Reaction (PCR) Dan Loop-mediated Isothermal Amplification (LAMP) Dalam Diagnosis Molekuler. Odonto Dent J. 2016;3(2):145-51.

13. Kudyba HM, Louzada J, Ljolje D, Kudyba KA, Muralidharan V, Oliveira-Ferreira J, et al. Field evaluation of malaria malachite green loop-mediated isothermal amplification in health posts in Roraima state, Brazil. Malar J [Internet]. 2019;18(1):1-7. Available from: https://doi.org/10.1186/s12936-019-2722-1

14. Vásquez AM, Zuluaga L, Tobón A, Posada M, Vélez G, González IJ, et al. Diagnostic accuracy of loopmediated isothermal amplification (LAMP) for screening malaria in peripheral and placental blood samples from pregnant women in Colombia. Malar $J$ [Internet]. 2018;17(1):1-11. Available from: https://doi.org/10.1186/s12936-018-2403-5

15. Ponce C, Kaczorowski F, Perpoint T, Miailhes $P$, Sigal A, Javouhey E, et al. Diagnostic accuracy of loopmediated isothermal amplification (LAMP) for screening patients with imported malaria in a non-endemic setting. Parasite. 2017;24.

16. McCreesh P, Mumbengegwi D, Roberts K, Tambo M, Smith J, Whittemore B, et al. Subpatent malaria in a low transmission African setting: A cross-sectional study using rapid diagnostic testing (RDT) and loopmediated isothermal amplification (LAMP) from Zambezi region, Namibia. Malar J [Internet]. 2018;17(1):111. Available from: $h$ ttps://doi.org/10.1186/s12936-018-2626-5

17. Sema M, Alemu A, Bayih AG, Getie S, Getnet G, Guelig D, et al. Evaluation of non-instrumented nucleic acid amplification by loop-mediated isothermal amplification (NINA-LAMP) for the diagnosis of malaria in Northwest Ethiopia. Malar J. 2015;14(1):1-9. 